\title{
МІСЦЕВЕ САМОВРЯДУВАННЯ НА БУКОВИНІ У СКЛАДІ АВСТРІЙСЬКОї ІМПЕРІЇ У ДРУГІЙ ПОЛОВИНІ XVIII СТ. (3 1774 P. ПО 1786 P.)
}

Бутирін $\epsilon$. 0 .

Проаналізовано причини поділу Речі Посполитої між Австрією, Пруссією та Росією. Зазначено, що ініціатива приєднання Буковини належала безпосередньо імператору Иосифу II. Акцентовано на тому, що на Буковині до приєднання цих земель до Австрії діяла система управління під Молдовською зверхністю, в якій чиновники не отримували платню. На основі аналізу правової системи Австрії досліджено організаційно-функціональні засади місцевого самоврядування на Буковині у складі Австрійської імперії.

Ключові слова: дистрикт, староста, цинут, магнати, шляхта, військова адміністрація, патент.

Проанализированы причины раздела Речи Посполитой между Австрией, Пруссией и Россией. Отмечено, что инициатива присоединения Буковины исходила непосредственно от императора Иосифа II. Акцентировано внимание на том, что на Буковине до присоединения этих земель к Австрии действовала система управления под Молдавским превосходством, в которой чиновники не получали зарплату. На основании анализа правовой системы Австрии исследованы организационно-функциональные основы местного самоуправления на Буковине в составе Австрийской империи.

Ключевые слова: дистрикт, староста, цинут, магнаты, шляхта, военная администрация, патент.

The reasons for dividing the Commonwealth of Both Nations between Austria, Prussia and Russia have been analyzed in the paper. It has been noted that the initiative to join Bukovina came directly from Emperor Joseph II. It has been emphasized that in Bukovina, prior to the annexation of these lands to Austria, there was a system of government under the Moldavian superiority in which officials did not receive payment. On the basis of the analysis of the Austrian legal system, the organizational and functional foundations of local self-government in Bukovina within the Austrian Empire have been investigated.

Bukovina consisted of four tzinuts: Chernivtsi, Vyzhnytsia, Seretsky, Suchavskyi, and a separate Rus-Kimpolunsky (Dovgopolsky) regions. Tzinut consisted of 12 suburbs, each of which in turn covered 10 communities.

Each tzinut was headed by a starosta ("parkalab"), appointed by the Moldavian ruler, whose jurisdiction was taxes and litigation. A starosta controlled three pysari ("logothete"). One of them was responsible for taxing the trenches and the other was dealing with correspondence and court cases. Depending on the size of the subordinate territory, up to 80 court officers reported to starosta, namely: foot court officials ("byrany"), under the auspices of the captain; equestrian court officials ("Umbalators"), led by a lieutenant; local police ("Arnauts") led by Corporal.

At the initiative of General K. von Enzenberg, a regional office was established and was directly under the control of the head of the military government. The staff of the newly formed body consisted of a chairman, a Wallachian secretary, a protocolist, a chancellor and interpreters - Wallachian and Polish. The cashier and the accountant were in charge of the finances, and the legal case was entrusted to a staff auditor, under the jurisdiction of which there were several chancellors and two district auditors.

However, on November 1, 1786, Joseph II abolished the Military Administration and annexed Bukovina to the Kingdom of Galicia and Lodomeria, which became its 19th district. Bukovyna joined the Galician province as a political and administrative district on February 1, 1787. Bukovina's legal status was confirmed by a Cesarean patent of September 29, 1790, and lasted until April 4, 1849. Since those events the Teresian political views on Galicia as a temporary acquisition and integration of the Kingdom of Galicia and Lodomeria into the Austrian state system began.

Key words: district, starosta, tzinut, magnates, shliakhta, military administration, patent.

Постановка проблеми та іï актуальність. Унаслідок завершення Північної війни (1700-1721рр.) європейські країни опинилися у новій геополітичній ситуації, в якій найпотужніші держави - Австрія, Пруссія, Росія та Франція - намагалися завершити переділ східної периферії вестфальського простору та прилеглих до нього регіонів. Цю нову реальність наочно відчула на собі Річ Посполита після смерті свого короля Августа II Саксонського у 1733 р. Наступні події були позначені як боротьба за польську спадщину, в якій взяли безпосередню участь Австрія, Саксонія, Росія та Франція, кожна з яких політично та військово підтримувала свого кандидата на королівський престол.

До цього зовнішнього чинника додалась внутрішньополітична криза у вигляді постійної боротьби між магнатеріями, якій конче ослаблена королівська влада вже не могла завадити. Польський історик (а у 1908-1913 рр. і намісник Галичини) М.Г. Бобжинський про тогочасну Польщу писав, що «то був образ грубого матеріалізму, позбавлений світла <...> Непроходима пітьма огорнула польські уми<...> Королівські міста занепали економічно, а унаслідок насильства шляхти вони втратили свою незалежність. Доля приватних міст не дуже відрізнялася від долі села, де шляхтич вважав селян річчю, своїм маєтком<...> Та сама іржа, що пожерла народ, не пощадила також і магнатів. І вони назагал діяли кожний задля власної особистої амбіції і користі<...> Загальна анархія, що закінчилася першим розбором краю [1].

Метою статті $\epsilon$ розгляд місцевого самоврядування на Буковині у складі Австрійської імперії у другій половині XVIII ст.

Виклад основного матеріалу. Показово, що, попри наявний занепад державного устрою, більша частина шляхти федерації обох народів не вважала за потрібне його реформувати. I лише незначна частина нобілітету розуміла потребу в негайних радикальних змінах. Саме

Бутирін Є. О., 2019 
вони, долаючи супротив консервативної більшості магнатів та шляхти, намагались провести у 70-х рp. XVIII ст. військову та фінансову реформи, а на початку 80-х рр. й реформувати право та судочинство. Зокрема, лунали пропозиції щодо надання містам більшої самоврядності та послаблення кріпосницької залежності селян [2, с. 39]. Зазначимо, що це були не пусті пропозиції. Що стосується самоврядування, то 18 квітня 1791 р. був прийнятий Закон про вільні королівські міста в державах Речі Посполитої [3, с. 69-78].

Війна Російської та Оттоманської імперій додала нової динаміки в розвиток геополітичної ситуації в Європі, і занепокоєний іï наслідками Фрідріх II ще у 1769 р. спрямував до м. Санкт-Петербургу пропозиції щодо розділу Речі Посполитої, напрацьовані графом Лінаром.

Посеред сепарованої польської шляхти існувало стійке переконання, що «чорні орли» - Австрія, Пруссія та Росія - завжди будуть сваритися щодо «білого орла»Речі Посполитої - і не зможуть нічого удіяти. Але сталося дещо інакше, адже одній німкені та двом німцям вдалося домовитись. Не бажаючи посилення Австрії та Пруссії за рахунок польських земель, Росія тривалий час відмовлялась від участі в цьому проєкті, але після того, як Австрія пристала на прусські пропозиції, довелось зголоситися й Росії.

Рішення щодо розділу було спочатку таємно ухвалене 4 січня 1772 р. між Пруссією та Росією у м. Санкт-Петербурзі [4, с. 131-137]. 25 липня того ж року в російській столиці було підписано й окрему конвенцію між Австрійською та Російською імперіями. За домовленостями до Пруссії відійшло Польське Помор'я та частини Куявії й Великої Польщі. Росія набула Інфлянту й зхідну частину Білорусі до Зхідної Двіни, Дніпра та його правої притоки Друті і суходільної лінії, що тяглася від верхів'я Друті до Західної Двіни. Австрія залучила до себе Малу Польщу і Галичину з Руським, Белзьким і західними околицями Волинського та Подільського воєводств.

Дивно, але сучасні науковці наводять будь-які дати щодо юридичного оформлення розподілу Речі Посполитої, не посилаючись на конкретні джерела. Так, B.М. Клапчук зазначає, що перший поділ датований 5 червня 1772 р., коли повноважні представники Пруссії, Австрії та Росії підписали у Петербурзі договір, за яким вони забрали території по периметру Речі Посполитої. М. Кріль наполягає, що ця подія відбулась 19 лютого 1772 р. В.Ковальчук зазначає: «На початку 1772 р. між Австрією, Пруссією та Росією відбулися перемовини стосовно розподілу Речі Посполитої, що закінчилися підписанням окремої декларації, яка забезпечувала трьом названим державам однакову участь у ії розподілі. Ї̈̈ підписала 19 лютого 1772 р. австрійська імператриця Марія-Терезія, 28 лютого - прусський король Фрідріх II, 5 березня - російська імператриця Катерина II». Насправді ця подія відбулась 25 липня 1772 р. [5].

Окупанти намагались отримати від польської влади затвердження розбору краю. 19 квітня 1773 р. у м. Варшаві був скликаний сейм, який, працюючи в умовах російсько-пруссько-австрійської військової присутності, 30 вересня 1773 р. ратифікував поділ Речі Посполитої більшістю голосів [6].

I хоча Ї̈̈ Апостольська Величність Імператриця-Королева Марія-Терезія публічно скаржилася з приводу участі у прилученні польських земель, наголошуючи, що тільки слабкість турків та неможливість розраховувати на допомогу Англії та Франції, побоювання відносно вірогідної війни з Росією та Пруссією, бідність та голод, що спіткали іï землі, примусили їі до того неправедного кроку, який заплямував їі правління й отруїв її дні. На ці скарги саркастично відреагував іï спільник в цій справі Фрідріх II Великий: «Вона плакала, проте своє брала» [7, с. 104].

Мало хто сьогодні згадує у наукових розвідках та підручниках той факт, що фактичний поділ Речі Посполитої розпочався не з пропозицій Фрідріха II, а з військових операцій австрійської армії щодо Спижу та Сяндеччини. Скориставшись кризовою ситуацією та внутрішньою анархією, яка утворилась в Речі Посполитій, австрійські війська за наказом Йосифа II зайняли спочатку Спиж у 1769 р. як угорську заставу, яка належала Польщі з 1412 р., а трохи пізніше - у 1770 р. частину Сяндеччини.

Одночасно з наказом військовим про окупацію було видане цісарське веління про пильний пошук у віденських та будапештських архівах правовстановлюючих актів щодо тих земель. I коли Річ Посполита подала ноту протесту щодо окупації, у відповідь вона отримала офіційний акт від 25 жовтня 1770 р., в якому містився вивід прав Угорщини стосовно прилучених територій. Однак цим все не завершилось. Цісар наказав продовжувати пошук в архівах правовстановлюючих документів на права австрійської корони щодо інших польських земель. Архіваріуси працювали, а тим часом Австрія, Пруссія та Росія на дипломатичному рівні вже домовились про поділ Речі Посполитої. До 1772 р. вже було готове правове підґрунтя - історична довідка за підписом угорського історика І. Бенцура «Вивід прав королівства Угорщини до Малої (Червоної) Русі і Поділля та Чехії до князівства Освєнціму і Затора». «Вивід<...>» був виданий у м. Відні в надвірній друкарні чотирма мовами - латиною, німецькою, французькою та польською [8]. Зокрема, у «Виводі<...>» зазначалось, що згідно зі свідоцтвами найвіродостойніших польських та угорських істориків XI та XII ст., а також багатьох інших автентичних документів (до «Виводу<...>» додавалось 17 правовстановлюючих документів. 12 документів підтверджували права Угорщини на Галичину, а 5 - права Чехії на князівства Освєнцім та Затор) угорські королі були тоді (а навіть і давніше) на основі найсправедливіших прав посідачами Королівства Малої (Червоної) Русі (Regnum Russiae), а передовсім двох частин цього Королівства - Галичини і Лодомерії, які відтоді і дотепер належать до королівського угорського титулу, з яких одна простягається далеко на Поділля, а друга займає значну частину Волині, а також Перемиської землі й інших значних територій.

Юридичне оформлення територій, що відійшли Габсбурзькій монархії, відбулося в тому ж році. Цісарівна Марія-Терезія 11 вересня поставила свій підпис під декретом, відповідно до якого щодо земель Королівства Галичини і Лодомерії (Konigreich Galizien und Lodomerien) проголошувалось відновлення прав (terrae revindicatae), а королівство ставало невід'ємною частиною імперії [9, с. 9-10], бо галицькі землі входили до складу Угорщини під зверхністю короля Андраша II, який з 1205 р. титулував себе rex Galiciae et Lodomeriae. Було нагадано й те, що з 1526 р. угорська королівська корона належала домові Габсбургів. Відтоді до титулу 
імператора додалось формулювання «король Галичини і Лодомерії».

Дізнавшись про це, Фрідріх II, ледве стримуючи свою радість, підбадьорював австрійського посланника при прусському дворі барона фон Світена: «Шукайте далі, може статися, що у вас знайдеться ще право на якесь польське воєводство» [10, с. 12].

Нагадаємо, що Підкарпатська Русь (Закарпаття) ще з XI ст. була частиною Королівства Угорського, а отже, ще до переділів Речі Посполитої входила до складу Австрійської імперії як частина Пожонського (Братиславського) намісництва Угорського королівства.

Так само агресивно діяли Габсбурги й унаслідок поразки, яку зазнала Оттоманська імперія у війні з Росією. Знаний дослідник історії Буковини австрійської доби Р.Ф. Кайндель у своїй габілітаційній роботі дослідив процес приєднання Буковини до Австрійської імперії і піддав конструктивній критиці румунського історика Д. Веренку, який, на його думку, помилково визначив порядок розробки планів щодо приєднання Буковини. Р.Ф. Кайндель зазначив, що ініціатива інкорпорації належала не державному канцлеру i графу В.А. Кауніцу, а безпосередньо імператору Йосифу II. Йосиф II ще у 1772 р. обговорював плани приєднання до імперії частини Валахії. Однак у наступному році у нього вже з'явився намір приєднання частини Північної Молдовії, що межувала з Галичиною та Семигороддям, себто Буковини. У роботі наводився уривок 3 листа Йосифа II до Марії-Терезії від 19 червня 1773 р., де обґрунтовувалася потреба приєднання цієї території [11, с. 26]. Отже, окупація Буковини розпочалася ще до виходу з території краю російських військ, на що австрійський уряд отримав згоду російського командування. Йосиф II 8 серпня 1774 р. віддав наказ щодо зайняття Буковини і Хотинської райї [12, с. 10]. 31 серпня 1774 р. австрійські війська увійшли до Чернівців, а за наступні три доби була окупована майже вся Буковина [13, с. 131]. Австрійсько-турецьку конвенцію щодо уступки Портою «на вічні часи» Австрії Буковини, окрім Хотинської райї, було підписано 7 травня 1775 р. 12 травня наступного року ті ж самі сторони підписали конвенцію щодо демаркації північно-східних кордонів між Чернівецьким цинутом і Хотинською райєю [14, с. 43; 46-48]. Вона набула статусу герцогства, тому в титулі імператора з'явилось формулювання «герцог Буковини». Використовувались назви «Буковинський дистрикт», «Чернівецький генералат» та «Галицький прикордонний генералат» [15, с. 172]. 8 лютого 1775 р. під проводом військової адміністрації Буковина отримала особливий статус, який передбачав культурну, релігійну, правову та економічну автономію. Було розпочато майже десятирічний період панування військової адміністрації, завданням якої було інтегрувати герцогство в австрійську державу, поширити на нього загальноімперське законодавство та визначити вектор соціально-економічного розвитку.

На чолі військового правління стояв голова військової адміністрації, який сконцентрував у своїх руках всю повноту адміністративної та судової влади. У свою чергу голова був підпорядкований Надворній військовій раді, дорадчому органу при імператорові, а також військовому командуванню у м. Львові [16]. Першим очільником краю став генерал, під чиїм безпосереднім командуванням була окупована Буковина, - Г. фон Сплені (нім. Gabriel Anton von Splény von Miháldy). Історія зберегла для нас Один із його звітів перед Віднем (1775 р.) «Опис Буковинського дистрикту: за його минулим і донині ще існуючим станом, разом з пропозиціями, як у майбутньому можна було б поліпшити дотеперішній статус краю в політиці та економіці» [17].

12 жовтня 1777 р. Буковина присягнула на вірність Габсбургам. До присяги були приведені всі стани краю, що свідчило про прийняття населенням австрійського підданства. Більшість населення становили українці (себто русини), молдовці, румуни та ін. Відряджений Йосифом II для знайомлення з краєм та його населенням австрійський офіцер інформував імператора, що більша частина тутешніх мешканців складалася 3 «руснаків», що переважно говорять люди «по-руськи», і тільки приблизно чверть населення говорить молдовською [18, с. 5-10]. Проте серед місцевої шляхти переважали молдовці, а у попередні часи державною мовою вважалася молдовська, тому й урядовці австрійської військової адміністрації Буковини сприймали місцеве населення як волохів. Однак румунський політичний діяч початку XX ст. А. Ончул неупереджено зазначав, що більшість буковинського населення під час австрійської окупації була української національності. Згодна з цим і традиція [19, с. 5-10]. Наприкінці XVIII ст. посилилася німецька колонізація Буковини. До середини наступного століття вже існувало 19 німецьких колоній. У цей же час виникли й п'ять поселень росіян-старообрядців. Більшість населення мешкала в селах, окрім м. Чернівці, яке у 1776 р. налічувало лише 2 тис. містян [20, с. 121,194$]$. Існувало ще два містечка - Садгора (2 871 мешканець) та Вижниця (4 447 мешканців). Саме на м. Чернівці припадала найбільша концентрація торгового, ремісницького та промислового населення, а також незначна кількість інтелігенції. Що стосується ремісників, що мешкали в містах та містечках (Чернівці, Садгора, Вижниця, Кіцмань), то вони були представлені шевцями, кушнірами, кравцями, ткачами, ковалями, теслярами [21]. Ремісницькі цехи почали засновуватись ще у 1783 р., а на початку наступного століття їх налічувалось 19 [22]. Що стосується промислового виробництва, то найбільш поширеною галуззю була харчова. Також вироблялись будівельні матеріали, розвинутою була деревообробка. Виникла низка скляних гут - Стара Гута, Красна, Нова Гута [23]. Саме німецькі колоністи домінували в торгівлі, промисловості та ремісництві.

Проте основну масу населення складали селяни, яких в краї на кінець XVIII ст. налічувалось приблизно 16 тис. родин [24]. Їхнє тяжке становище зумовлювало піднесення селянського руху, на який жорстко реагувала влада. Однак репресії не досягали своєї мети. Так, у звідомленні окружного комісару Буріяна від 18 лютого 1839 р. знаходимо таке: «Поваги до панів немає, а вибрані громадою представники заміщують всі власті» [25, с. 21]. Протистояння між сільськими громадами було тривалим. Так, в петиції, яку у серпні 1840 р. направили цісареві 22 громади околу, зазначалось, що за останню чверть століття на повагу цісаря та губернатора Галичини було спрямовано понад 60 скарг. Тричі делегатів приймав цісар, але для селян так нічого й не було зроблено.

У цих складних соціальних умовах Г. фон Сплені став до реорганізації адміністративного устрою та організації органів місцевого самоврядування, бо він дуже 
критично ставився до тієї системи управління, яка панувала на Буковині під Молдовською зверхністю. Зокрема, він писав, що весь адміністративний персонал, за винятком арнаутів, не отримував від князя ніякої платні. Отже, легко собі уявити, як ці чиновники виконували свою службу і як вони пригнічували народ. Вищі посадовці виконували свої обов'язки не довічно, адже їх каденція не перевищувала трьох років. Посада діставалась тому з кандидатів, хто пропонував найбільшу ціну. I після цього його зусилля були спрямовані на повернення витрачених грошей та збагачення у найкоротший час всіма правдами та неправдами, адже такі посадовці зовсім не переймалися страхом покарання [26, с. 47].

Фактично Буковинський дистрикт входив до кількох адміністративних одиниць імперії - Руського і Молдовського кимполунгів та Чернівецького і Сучавського цинутів. Кимполунгами називали адміністративні одиниці, що характеризувались значною територією з гірським ландшафтом, невеликою чисельністю мешканців та слабкою інфраструктурою і маленьким адміністративним апаратом. У свою чергу цинути являли собою великі адміністративно-територіальні одиниці Молдовського князівства, які були поділені на дрібніші одиниці - околи.

Так, з 1 серпня 1794 р. Буковина складалася з чотирьох цинутів (Чернівецький, Вижницький, Серетський, Сучавський та окремий Русько-Кимполунзький (Довгопільський) окіл [27]). Цинут складався 312 околів, кожний з яких обіймав по 10 громад.

Кожний цинут очолювався старостою (паркалабом), що призначався молдовським володарем, у компетенції якого були податки та судочинство. У підпорядкуванні старости знаходились три писарі (логофети), один з яких оприходував податкові збори з окопів, а інші переймалися кореспонденцією та судовими справами. Залежно від розміру підлеглої території в підпорядкуванні старости знаходились до 80 судових служителів (піші судові чиновники (бирани) під зверхністю капітана, кінні судові чиновники (умбалатори) на чолі з лейтенантом, крайова міліція (арнаути) під проводом капрала).

У свою чергу окіл підпорядковувався призначеному наміснику, на якого покладався обов'язок здійснювати судочинство в дрібних справах, тим самим надаючи допомогу в цій функції старості цинуту. Для збору податків у кожний окіл призначалися два злоташі. Низовим рівнем цієї адміністративної ієрархії виступало село, на чолі якого стояв сільський староста (двірник), на допомогу якому призначалися три підстарости (ватамани).

У 1778 р. генерала Г. фон Сплені було заміщено генералом К. фон Енценбергом (нім. Karl von Enzenberg), який також добре розумівся та орієнтувався в буковинських справах і продовжив реорганізацію місцевого самоврядування. За його ініціативою було створено крайову канцелярію, що знаходилась у безпосередньому підпорядкуванні очільника військового правління. Штат новоствореного органу налічував голову, волоського секретаря, протоколіста, канцеляриста та перекладачів - волоського і польського. Фінансами опікувався касир і рахівник, а юридична справа покладалася на штабсаудитора, в підпорядкуванні якого зна- ходилось кілька канцеляристів та два дистрикт-аудитора [28, с. 185-243].

Зазнав змін й адміністративний поділ. У краї були створені два дистрикти - Чернівецький та Сучавський, які обійняли Руський та Молдовський кимполунги, що продовжували зберігати певні особливості самоврядування. Дистрикти обіймали по сім околів, до складу яких входило по 110 та 133 населених пункти.

К. фон Енценбергом докладались зусилля щодо розбудови м. Чернівці. Це місто поступово перетворювалось на справжній адміністративний центр краю. 31782 р. керував містом громадський суд у складі судових засідателів.

Відповідно до рескрипту двору, датованого 25 серпня 1785 р., Надвірною військовою радою було доручено Військовій адміністрації розробити проєкт щодо міського порядку для міст Буковини - Чернівців, Сучави та Серету. У січні наступного року розроблений проєкт міського статуту був спрямований К. фон Енценбергом на розгляд до м. Львова, а звідти вже до м. Відня, де клерки Надвірної ради достатньо швидко відредагували проєкт, прибравши з нього найбільш прогресивні задумки та зробивши декілька доповнень. 8 лютого 1786 р. Надвірна військова рада затвердила міський статут, який після цього набув юридичної сили для буковинських міст Чернівців, Сучави та Серету. Це був нормативно-правовий акт, який вперше визначив правовий статус буковинських міст та той порядок, за яким повинні були жити ці міста. Відповідно до статуту мешканці міста християнського віросповідання складали міську громаду. Вже у травні 1786 р. під пильним наглядом комісара Військової адміністрації відбулись вибори до міського суду м. Чернівців, на яких було обрано міського суддю та чотирьох радників [29, с. 19]. Суд наймав діловода, канцеляриста, поліціанта, п'ятьох слуг та двох нічних сторожів. В установі було запроваджене протокольне діловодство, вівся бухгалтерський облік прибутків та витрат, визначалось грошове утримання для службовців [30, с. 185-243].

Однак вже 1 листопада 1786 р. Йосиф II скасував Військову адміністрацію та приєднав Буковину до Королівства Галичини і Лодомерії, яка стала його 19 округом [31, с. 13]. Фактично Буковина доєдналася до складу Галицької губернії як політико-адміністративний округ 1 лютого 1787 р. [32]. Таке правове становище Буковини було підтверджене цісарським патентом від 29 вересня 1790 р. і протрималось аж до 4 квітня 1849 р. [33]. Саме з цих подій починається виразний розрив з терезіанськими політичними поглядами на Галичину як на тимчасове придбання. Розпочинається інтеграція Королівства Галичини і Лодомерії до австрійської державної системи [34, с. 4-5].

Висновки. Таким чином, у статті розглянуто та проаналізовано причини поділу Речі Посполитої між Австрією, Пруссією та Росією. Акцентовано на тому, що на Буковині до приєднання цих земель до Австрії діяла система управління під Молдовською зверхністю, в якій чиновники не отримували платню. На основі аналізу правової системи Австрії досліджено організаційно-функціональні засади місцевого самоврядування на Буковині у складі Австрійської імперії. 


\section{Література}

1. Bobrzynski M. Dzieje Polski w zarysie. Warszawa : Nakład Gebethnera i Wolffa, 1879. S. 420.

2. Lesnodorski B. Dzieło Sejmu Czteroletniego, 1788-1792 : studium historyczno-prawne. Wroctaw : Wydawn. Zakladu Narodowego im. Ossolińskich, 1951. 473 s. S. 39.

3. Miasta nasze krolewskie wolne $w$ panstwach Rzeczypospolitej. Konstytucja 3 maja. Dokumenty naszej tradycji / Opracowal Jerzy Lojek. Lublin : Wydawnictwo lubelskie, 1984. S. 69-78.

4. Под стягом России: сборник архивных документов. Москва : Русская книга, 1992. С. 131-137.

5. Клапчук В.М. Адміністративно-територіальний поділ території сучасної Івано-Франківської області: від короля Казимира III великого до незалежної України. Карпатський край. 2012. № 2. С. 4-17 ; Кріль М. Організація австрійського управління на Добромильщині в останній третині XVIII - на початку XIX ст. Літопис Бойківщини. 2012. Ч. 2/83(94). С. 62-70 ; Ковальчук І.В. Роль Галичини у державотворчих процесах Австрії та Австро-Угорщини (1772-1918). Наукові проблеми державотворення України : матеріали наукової конференції. Вінницький національний технічний університет, 7 листопада 2017 р. С. 56-63 ; Под стягом России : сборник архивных документов. Москва : Русская книга, 1992. С. 137-140.

6. Kraszewski J. Polska w czasie trzech rozbiorów 1772-1797 : studia do historyi ducha i obyczaju. T. 1. Poznań : Żupański, Jan Konstanty ; Drukarnia J. I. Kraszewskiego Dr W. Lebiński, 1874. 327 s. ; Kaplan H. The first partition of Poland. New York: Columbia University Press, 1962. 215 p.

7. Magenschab H. Josef II. Revolucionář z boží milosti. Praha : Brána : Knižní klub, 1999. 241 s. S. 104.

8. J. Benezur Jurium Hungariae in Russiam Minorem et Podoliam. Bohemiaeque in Osvenciensem et Zatoriensem Ducatum praevia explicatio. Vindob, 1772 ; німецькою: Vorläufige Ausführung der Rechte des Königreichs Hungarn auf Klein oder Roth Reussen und Podolien und des Königreichs Böheim auf die Herzogthümer Auschwitz und Zator. Wien, 1772 ; французькою: Expose preliminaire de droits du Royaume de Hongrie sur Klein ou Roth Reussen et Podolia et du Royaume de Böheim sur les duchés d'Auschwitz et de Zator. Vienne, 1772 ; та польскою: Wywod poprzedzajacy praw Króny Węgierskiey do Rusi Czerwonejy do Podola, tak iako Koróny Czeskiey do Xięstw Oswiecimskiego y Zatorskiego. W Wiedńiu, 1772.

9. Стеблій Ф. Часи австрійського абсолютизму (1772-1860-ті роки). Адміністративно-правовий статус. Система управління. Історія Львова : У 3 т. / Інститут українознавства ім. І. Крип'якевича НАН України / Редкол. : Я. Ісаєвич, М. Литвин, Ф. Стеблій, Л. Батрак. Львів : «Центр Європи», 2007. 559 с. Т. 2 : 1772 - жовтень 1918. С. 9-10.

10. Свистун Ф. Прикарпатская Русь подъ владеніемъ Австріи : [в 2 ч.]. Львів : Тип. Ставропиг. Ин-та, 1895. 350 с. Ч. І. С. 12.12

11. Kaindl R. F. Die Erwerbung der Bukowina durch Österreich. Czernowitz, 1894. S. 26.

12. Kaindl R. F. Die Erwerbung der Bukowina durch Österreich. Czernowitz, 1894. S. 10.
13. Beer A. Die erste Theilung Polens. Wien : C. Gerold's Sohn, 1873. XIV, 329. s. S. 131.

14. Polek J. Die Erwerbung der Bukowina durch Österreich. Czernowitz : Pardini, 1889, S. 43, 46-48.

15. Werenka D. Bukowina's Entstehen und Aufblühen, Maria Theresia's Zeit. I. Teil : 1772 - Juni 1775. Wien : J. Comission bei F. Tempsky, 1892. S. 172.

16. Державний архів Чернігівської області (ДАЧО). Ф. 1178. Оп. 1. Спр. 1. Арк. 1-2.

17. Габріель фон Сплені. Опис Буковини / пер. з нім., передм. і ком. О.Д. Огуя, М. М. Сайка. Чернівці : Рута, 1995. 110 c. ; General Spleny`s Beschreibung der Bukowina / Herausgegeben von Dr. Johann Polek. Czemowitz, 1893.

18. Oncial A. Chestia românească in Bucovina. Viața Românească. Vol. 31. 1913. № 10. P. 5-10. P. 6.

19. Oncial A. Chestia românească in Bucovina. Viața Românească. Vol. 31. 1913. № 10. P. 5-10. P. 7.

20. Fisher E., Żukowski L. Die Bukowina. Czernowitz, 1899. S. $121,194$.

21. ДАЧО. Ф. 3. ОП. 1. Спр. 68. Арк. 20.

22. ДАЧО. Ф. 1. Оп. 1. Спр. 988. Арк. 2-20.

23. ДАЧО. Ф. 1. Оп. 1. Спр. 184. Арк. 1-15.

24. ДАЧО. Ф. 1. Оп. 1. Спр. 1308. Арк. 20-105.

25. Селянський рух на Буковині в 40-х роках XIX ст. : збірник документів / Архівне управління МВС УРСР / Упоряд. Ф. Шевченко. - Київ: Укрполітвидав, 1949. 299 с. С. 21.

26. Габріель фон Сплені. Опис Буковини / пер. з нім., передм. і ком. О.Д. Огуя, М. М. Сайка. Чернівці : Рута, 1995. 110 c. C. 47.

27. ДАЧО. Ф. 29. Оп. 1. Спр. 28. Арк. 5, 6, 8.

28. Добржанський О.В. Система органів влади Буковини у складі Австрійської (Австро-Угорської) монархії. Icторія розвитку органів влади на території Чернівецької області : монографія / С.М. Гакман [та ін.]. Чернівці : Букрек, 2014. 812 с. С. 185-243.

29. Никифорак М. В. Державний лад і право на Буковині в 1774-1918 рр. : Автореф. дис. ... доктора юрид. наук : 12.00.01 «Теорія та історія держави і права, історія політичних і правових вчень». Київ, 2004. 36 с. С. 19.

30. Добржанський О.В. Система органів влади Буковини у складі Австрійської (Австро-Угорської) монархії. Icmoрія розвитку органів влади на території Чернівецької області : монографія / С. М. Гакман [та ін.]. Чернівці : Букрек, 2014. 812 с. С. 185-243.

31. Сайко М.М. Приєднання Буковини до Австрії і його вплив на соціально-економічний та політичний устрій краю (70-80-і роки XVIII - початок XIX ст.) : автореф. дис. ... канд. іст. наук : спец. 07.00.01 «Історія України». Чернівці, 1991. 21 c. C. 13.

32. Polek J. Die Vereinigung der Bukowina mit Galszsen im Jahre 1786. Czernowitz, 1900. S. 7.

33. ДАЧО. Ф. 3. Оп. 1. Спр. 68. Арк. 10.

34. Tokarz W. Galicya w początkach ery Józefińskiej w świetle ankiety urzędowej z roku 1783. Kraków, 1909. S. 4-5.

Бутирін $\epsilon$. O., кандидат юридичних наук, доцент кафедри теорії та філософії права одеського державного університету внутрішніх справ 